\title{
Towards a Re-conceptualization of Regional Development Paths: Is Leipzig's Media Cluster a Continuation of or a Rupture with the Past?
}

\author{
Harald Bathelt \& Jeffrey S. Boggs
}

\begin{abstract}
Version Post-print/accepted manuscript
Citation Bathelt, H., \& Boggs, J. S. (2003). Toward a reconceptualization of (published version) regional development paths: Is Leipzig's media cluster a continuation of or a rupture with the past?. Economic Geography, 265-293.
\end{abstract}

Copyright / License

Publisher's Statement This is the peer reviewed version of the following article: [Bathelt, H., \& Boggs, J. S. (2003). Toward a reconceptualization of regional development paths: Is Leipzig's media cluster a continuation of or a rupture with the past?. Economic Geography, 265-293.], which has been published in final form at:

http://onlinelibrary.wiley.com/doi/10.1111/j.1944-

$\underline{8287.2003 . t b 00212 . x / a b s t r a c t}$

This article may be used for non-commercial purposes in accordance with Wiley Terms and Conditions for Self-Archiving. 


\title{
Towards a Re-conceptualization of Regional Development Paths: Is Leipzig's Media Cluster a Continuation of or a Rupture with the Past?
}

\author{
Harald Bathelt \\ Faculty of Geography, Philipps-University of Marburg, \\ Deutschhausstraße 10, D-35037 Marburg, F.R.G., \\ E-mail: bathelt@mailer.uni-marburg.de
}

and

Jeffrey S. Boggs

Department of Geography, UCLA,

1255 Bunche Hall, Box 951524, Los Angeles, CA 90095-1524, USA,

E-mail: jboggs@ucla.edu

Acknowledgments. For supportive comments on earlier parts of this paper, we would like to thank Ron Boschma (Utrecht), Roberta Capello (Milan), Gordon Clark (Oxford), Meric Gertler (Toronto), Jennifer Lackey (Los Angeles), Päivi Oinas (Rotterdam), Dominic Power (Uppsala), Oliver Weigel (Leipzig) and Clare Wiseman (Frankfurt/ Main). This paper has also greatly benefited from constructive criticisms and insights of two anonymous reviewers, as well as helpful comments of Bjørn Asheim (Lund). We would also like to thank the DAAD (German Academic Exchange Service) and the DFG (German Science Foundation) for their financial support. Parts of this paper were presented at the Third Congress on Proximity "New Growth and Territories" in Paris, December 2001. 


\title{
Towards a Re-conceptualization of Regional Development Paths: Is Leip- zig's Media Cluster a Continuation of or a Rupture with the Past?
}

\begin{abstract}
This paper develops a model of regional development which is then used to examine the evolution of two media industries in Leipzig, Germany. We note that the city's current media cluster, centered on TV/ film production and interactive digital media, shares little in common with the city's once premier book publishing media cluster. Treating interactive learning as the primary causal mechanism driving economic growth and change, our conceptual framework incorporates both sectoral/ technological and political crises as mechanisms that rupture regional development paths. These regional development paths are not homogeneous, but instead consist of bundles of various technological trajectories. Regions recover from crises as their actors continually re-bundle local assets until they find a combination which generates growth. As a result of these crises, new growth opportunities may arise for entirely new and previously marginal industries. In turn, these expanding industries shape the region's development path.
\end{abstract}

Keywords. Leipzig, book publishing, TV/ film production, regional ruptures, regional development path 


\section{Introduction}

Throughout the 1990s, many scholars have applied evolutionary concepts to the analysis of regional development (e.g. Storper 1997; Belussi, and Gottardi 2000). This has provided deeper insights into the dynamics of the social organization of regional industrial systems, compared to those produced by earlier factor-centered approaches. Despite many benefits, the emphasis on evolutionary development also risks neglecting the effects of crisisdriven discontinuities and ruptures in regional context. ${ }^{1}$ In this article, we will use problems associated with a black-and-white understanding of evolutionary economic theory as a point of departure to argue for a need to re-conceptualize regional development paths. Our claims can be best demonstrated through a regional case study of Leipzig and its regional growth dynamics.

The recent development in Leipzig's media industry cluster underscores the problems of drawing exclusively on an evolutionary development framework which privileges technological continuity over rupture. Leipzig has a long history as a site of cultural production ${ }^{2}$ and learning. Its book publishing industry dominated the German book trade for well over two centuries, from the 18th century until the mid-20th century, centered in the city's Graphisches Viertel (Graphical Quarter). Today, Leipzig is but a shadow of its former glory as the hub of German-language book publishing. However, where this old media once reigned, a new media industry arose phoenix-like from Leipzig's proverbial ashes during the 1990s. Some

\footnotetext{
${ }^{1}$ Instead of focusing on the more frequent cyclical crises in economic reproduction, we focus on the more far-reaching political and sectoral/ technological crises which undermine the economic and societal compromises underlying capital accumulation.

${ }^{2}$ This paper deals with a subset of cultural products industries. These industries have for more than a decade been a site of intense geographical exploration from numerous perspectives (Storper, and Christopherson 1987; Lash, and Urry 1994; Scott 1996; Crewe 1996; Pratt 1997; Leyshon, Matless, and Revill 1998; Grabher 2002; Power 2002). Despite the specificities of these industries, the conceptual arguments we make here also hold for other industries, and not just cultural products industries.
} 
would invoke the concept of 'Marshallian atmosphere' to explain this development as one of continuity, similar to v. d. Berg et al. (2001:123) who conclude that "[p]erhaps the most important asset [in this development] is Leipzig's great media tradition.” Although continuity is an important issue we wish to emphasize the importance of crises in regional development which create discontinuities and disruption. There is a strong tradition of studies in economic geography focusing on crisis-driven restructuring and de-industrialization (e.g. Bluestone, and Harrison 1982, Massey, and Meegan 1982; Clark 1986; 1988; see also Hayter 1997). Since a lot of current work seems to favor claims of continuity over rupture, we would like to remind the readers of the importance of crises and ruptures in the agenda of economic geography and other social sciences and not to be blinded by continuity.

Avoiding black-and-white interpretations of regional development which draw on increasing returns, we develop a conceptual framework around interactive learning and its consequences over time. We explicitly incorporate sectoral/ technological and political ruptures into our model of regional development paths. From this, the basic structure of a model emerges in which bundles of overlapping technological trajectories drive regional development. In the next section, we argue that regional trajectories are much more complex than technological trajectories. They have to be treated differently because individual firm competencies cannot be aggregated into a comprehensive, homogeneous regional development path. Section three builds on the idea of windows of locational opportunity by incorporating theories of crises from the regulationist approach. This allows us to consider the impact of sectoral/ technological as well as political crises on those institutions which enable interactive learning. Such crises may, in turn, create growth opportunities for previously marginal technological trajectories housed in a region, whether an older industrial core or a former periphery. We analyze this process by introducing the concept of regional bundles.

In the empirical part, Leipzig is viewed through this conceptual lens. We first focus on its early role as a trade crossroads. In conjunction with Saxony's relative tolerance, this 
created a local environment in which the book trade flourished. By the mid-1700s, Leipzig's book fair came to dominate the industry, further locking-in its pivotal position within the German-language book market. Eventually Leipzig's Graphisches Viertel formed an industrial district of publishers, printers, paper-makers, book-binders, shipping agents and trade associations, anchoring a dense transactional network that supplied and coordinated Central European book markets. This lasted until the Second World War. In the post-War period, Leipzig lost this role as it was integrated into the Cold War international socialist division of labor. Geared towards dirigiste production, Leipzig was ill-prepared to hold its own against West German publishers after German Reunification in 1990. Local attempts to breathe new life into the Graphisches Viertel, as the site of a dynamic book publishing industry or modern visual media hub, had little success. However, within the city, a new visual media center emerged around the Mitteldeutscher Rundfunk (MDR), a public television and broadcasting network. While not as important as Berlin or Munich for motion picture production or television programming (Gräf 2001; Krätke, and Scheuplein 2001; Bathelt 2002), local-content language anchors MDR's suppliers to the region, altering Leipzig's regional development path. In the final section, we draw some conclusions from this regarding a re-conceptualization of regional development paths.

\section{Interactive Learning, Technological Trajectories and Regional Develop- ment}

This section synthesizes literature on interactive learning, technological trajectories and windows of locational opportunity. We point out the strengths and faults of these concepts to lay the groundwork for a model that explains regional development as an evolutionary process. In developing the concept of regional development path, we argue that techno- 
logical trajectories cannot easily be aggregated into a single regional trajectory. Instead we treat regional development paths as bundles of overlapping technological trajectories. ${ }^{3}$

\section{Conceptual Point of Departure: Interactive Learning and Technological Trajectories}

As opposed to traditional economic thinking, evolutionary economists treat endogenous technological change as the primary cause of growth and prosperity (Nelson, and Winter 1982). In this view, interactive learning is a critical process to understand that innovation also results from search activities and experiments in or related to the production process (Malecki 1991). These search activities are contingent; searchers do not know if they will succeed. Thus, uncertainty plagues the innovation process. Additionally, interactive learning implies that innovation is not the result of solitary world-class scientists and technicians. Instead, innovation depends on regular communication within a firm (Arrow 1962; Rosenberg 1982) and outside of it (Lundvall 1988; Gertler 1993; 1996).

Interactive learning is crucial for innovation processes in any technology, complex or simple (Malecki 1991). Innovation depends on competencies distributed among a variety of different actors. This requires interactive problem-solving and collective action. Storper (1997) argues the goals of complex innovation processes are rarely pre-determined. They become defined through actions while the process is underway. As a result of reflexive behavior, agents constantly redefine goals according to new information about the success of previous actions. Interactive innovation processes rely on relations between particular people and conventions as expressed in accepted norms, rules and practices, allowing agents to co-operate on particular projects (Boyer, and Orléan 1992). Conventions enable supplier and customer interaction, intra-firm communication, and labor market pooling (Storper 1997). The result of

\footnotetext{
${ }^{3}$ In this paper, we use the term 'technology' broadly with respect to the ways in which humans shape their environment. This also includes particular organizational patterns and institutions and not just tools, machines or other technical equipment (see also Malecki 1991). This implies that technological progress in society is not just, in a narrow sense, hardware-driven.
} 
convention-based interactive learning is often incremental improvement rather than revolutionary technological change in product and process design.

\section{Spatial Implications of Interactive Learning}

Interactive learning has distinct consequences for the spatial organization of production and innovation because conventions and social relations are only constantly restructured through systematic feedback between agents. Adjusting dynamic conventions and relations requires the co-presence of agents, which is most efficiently conducted through co-location (Storper 1997). Some conventions cannot be easily transferred over large distances to other social contexts (Maskell, and Malmberg 1999). As a consequence, industry clusters can develop which are characterized by close inter-firm interaction, proximity and systematic interactive learning (Storper 1992; Asheim 1999). In turn, these industry clusters contribute to the parallel evolution of technological trajectories.

Frequent interaction between specialists in these firms promotes the generation of implicit, tacit knowledge which is not easily codified. This knowledge is localized in that it is restricted to particular actors, firms and places where this interaction takes place (Maskell, and Malmberg 1999). Contextualized or embedded knowledge constantly enriched by localized knowledge is less prone to standardization, ubiquitification and relocation. Therefore, tacit and even contextualized codified knowledge generate competitive advantage to regional actors who share this knowledge (Asheim 1999; Gertler 2001; Belussi, and Pilotti 2001).

\section{Relational Consequences of Interactive Learning}

As a result of interactive learning, innovation is a social process. Innovation is also relational in character in that it takes place within a particular context and is path-dependent, yet, at the same time, contingent. This has distinct consequences for our understanding of regional production systems and their dynamics (Bathelt, and Glückler 2002a; 2002b). First, 
the direction and particular results of an innovation process are context-dependent because they are bound to the particular set of agents and institutions. Power asymmetries, trust and tacit knowledge structure relations between participating producers, their suppliers and customers (Granovetter 1985). This means that firms cannot be analyzed as independent entities; instead firms must be understood as being embedded in their respective socio-economic contexts (Grabher 1993a). However, embeddedness is not a purely spatial or local phenomenon, automatically based on proximity (Oinas 1997). Second, contextuality implies that change is path-dependent since it is based on past, often irreversible decisions regarding a particular technology (Dosi 1982; Arthur 1988). Past decisions constrain an actor's future decisions. Similarly, yesterday's social experience shapes today's interactive learning. This, in turn, shapes future search processes and innovations. Third, at the same time, future developments are not easily predictable because we never know when a branching point has occurred until after the fact. The outcomes of interactive learning and the way in which this affects future interactions are fundamentally open and undetermined; innovation thus is a contingent social process.

\section{Technological Trajectories}

In a relational perspective, the direction of technological change is shaped by existing technologies (Dosi 1982; 1988). The history of developing new and adapting existing technologies defines a particular technological trajectory. Along this path, firms accumulate specialized knowledge about specific technologies, their uses and organizing their uses. This knowledge is based on past experience gathered from interactive learning and collective action. In this conception, technological trajectories are set within the wider framework of a technological paradigm. This is a general model of how to understand and solve a set of technological problems based on a particular set of technological and scientific principles (Dosi 1988). A paradigm is shared by a larger group of actors; it is characterized by a common un- 
derstanding of technological characteristics, their potential and their limitations. Within a technological paradigm, heuristics and routines, such as accepted rules and habits (Nelson 1995), develop a distinct pattern and direction of problem-solving. They enable producers to communicate with their suppliers and customers and collectively decide upon product and process adjustments. Technological change is therefore an interactive process. Such heuristics ease the search process by pre-selecting potential solutions (see also Boschma, and Lambooy 1999). However, the application of a particular heuristic does not necessarily reveal all possible solutions or even a useful solution. Agents might have to adopt a new heuristic to be successful. Since different technological trajectories and technological paradigms might co-exist at the same time, agents finding no useful solutions might relocate to a new trajectory or even a different technological paradigm (Dosi 1982; 1988).

\section{Two Problems: Privileging Continuity and Lock-in}

While the literature recognizes revolutionary technological change, some debates and empirical studies in economic geography and other social sciences focus on technological lock-in and continuity. One important claim in the interactive model of technological change is that new technologies do not arise from one-time optimization processes but instead from a distinct history of contextual decisions leading to the actual invention (Boschma, and Lambooy 1999). This focus on continuity can, however, blur the view of change in that it overlooks the potential of unexpected ruptures and discontinuities. This is especially the case if a contingent view of technological change (i.e. Dosi 1988) is over-ridden by deterministic models of market dominance, such as in Arthur's (1988) model of market-share evolution for two competing technologies. Arthur (1988) argues that increasing returns from learning, network externalities and technological complementarities lead one technology to eventually dominate a given market. Increasing returns result as users recognize that adopting the innovation with larger market will generate more utility for themselves. As a consequence, tech- 
nological lock-in will occur. Lock-in results from rational individual behavior, implying that path dependence is irreversible; i.e., the users' decisions necessarily lead to total market dominance of one technology.

Arthur's (1988) model of path dependence is problematic because it can be rigidly interpreted to ignore the fact that competing technologies can co-exist in the medium- or longrun; e.g., IBM's and Apple's competing operating systems or national variations in railway gauge (for a critique, see also Clark, Tracey, and Lawton Smith 2001). In contrast, a more realistic conceptualization has to accept that less important trajectories still exist even when one technological trajectory dominates, sometimes in different social and spatial contexts. Furthermore, Arthur's (1988) model does not direct attention to technological obsolescence and rupture (i.e., why an established technology or technological paradigm is replaced by another). The model's major drawback is that the long-term structures that maintain technological lock-in (i.e. increasing returns to adoption) depend on events and decisions occurring in the early stages of the development path. This view results from the assumption that actors are atomistic utility-maximizers. In reality, however, economic actors are embedded in structures of social relations, through which they communicate decisions for a particular technology and within which power relations shape choices made (Bathelt, and Glückler 2002a; 2002b).

\section{Regional Development Paths as Bundles of Overlapping Technological Trajectories}

In addition to incorporating sudden political and sectoral/ technological ruptures, a model of regional development paths must also allow for technologically unrelated regional actors. The regional actors might be spread across several different technological paradigms, none of which may have their territorial core within that particular region. Recognizing this, leads us to develop a more robust model because only rarely does a region possess a homogeneous economy housing a single technological trajectory's agents. While some of the Italian industrial districts might come close to such a structure (e.g. Pyke et al. 1990), in most 
cases, several different and often unrelated technological trajectories co-exist within a particular region. Even in leading-edge high-technology regions, such as Boston's Route 128, the local economy is not a homogeneous set of industries tied into a single technological trajectory (Best 2000; Bathelt 2001b). Other non-core or 'normal' regions might lack potential to develop their own development path (Storper 1997; Hellmer et al. 1999). This case, for instance, refers to branch plant regions, backwaters hosting standardized activities for any number of technological trajectories. In these regions, actors employ technologies developed outside the region. The region's success depends on its ability to apply these technologies within the local production context and to reply to external market signals.

\section{Projecting Technological Competencies of Firms Into Regional Trajectories?}

Rigby, and Essletzbichler (1997) use aggregations of firms as proxies for regions and project the technological competencies of firms into a comprehensive regional development trajectory. Similar to the conceptualization of Prahalad, and Hamel (1990), they view firms as sets of competencies. Therein, firms possess an organizational structure allowing them to critically review and learn from past experience. Over time, they accumulate specialized capabilities and particular technological competencies, driving firm-specific learning. In this perspective, firms can be treated as a source of technological innovation (Cantwell, and Fai 1999). Rigby, and Essletzbichler (1997) contend that imitation requires proximity and that imitation falls as distance increases. They suggest that regions, just like firms, can be characterized by their technological and organizational structures. Thus, regional economic change is a consequence of variation and selection processes within that particular region. Regions with superior capacities for interactive learning and extended knowledge pools grow faster than other regions. Through this process particular regional innovation paths evolve (Rigby, and Essletzbichler 1997). 


\section{Regions are not Homogenized Actors}

We agree with this conceptualization on most accounts. However, this interpretation risks treating regions as actors. In contrast, Lawson (1999) approaches his notion of regional competence from a different angle. This term is explicitly related to the actors which define the regional production system and encompasses their overall ensemble of competencies. The people, firms and institutions within a region, however, rarely craft and implement coherent, collective actions binding them to a single, homogeneous technological trajectory. Lawson's (1999) conception works because he applies it primarily to regions such as industrial districts and creative milieus, all characterized by a relatively coherent economic structure. As pointed out above, however, regions are usually not characterized by a single technological trajectory. Therefore, it is problematic to assume that coherent firm behavior exists which simply translates into an equally coherent regional path as could be implied from Rigby, and Essletzbichler (1997).

Storper, and Walker (1989) avoid this aggregation problem by conceptualizing regional development paths in a different way. They first make foundational claims about the evolution of new technologies and industries and then examine the spatial implications of these claims. From this, they develop their general model of geographical industrialization, describing how the spatial organization of a particular industry evolves over time.

\section{How Today's Peripheries Become Tomorrow's Cores: Geographical Industrialization}

Storper, and Walker (1989) contend that a process of geographical industrialization generates uneven territorial development. This geographical industrialization ${ }^{4}$ revolves around three factors: territorial expansion, territorial differentiation and territorial instability of new technologies. Storper, and Walker (1989) link territorial expansion to the creation of

\footnotetext{
${ }^{4}$ When we use the term 'industrialization' we refer broadly speaking to the evolution of technological trajectories within a particular industry or value chain.
} 
novel industries, which are based on new technologies. Furthermore, they argue that novel industries tend to form outside of existing industrial centers because they have few specific locational requirements at this stage (e.g., with respect to the characteristics of local suppliers, workers and infrastructure). This occurs because the necessary inputs do not exist anywhere and instead must be cobbled together from whatever materials are at hand (i.e., many locations offer an appropriate mix of modifiable inputs). Thus, numerous territories exist which could house the industry. A window of locational opportunity opens (see also Scott, and Angel 1987; Boschma 1997; Bathelt 1997).

Over time, Storper, and Walker (1989) assume that a handful of locales come to specialize in this once-novel industry, driving selective clustering. Furthermore, within this handful of locations a process of differentiation takes place, with each location playing a more-or-less important role in the production of the formerly novel commodities. Often, one location comes to dominate the industry and subordinates the remaining locations to the needs of its producers. By this time, the window of locational opportunity has long since shut.

Eventually, a stage of shifting centers can occur within which the dominant locales of the industry lose market share to other peripheral locales. Whether as a result of substitution for the territory's products or the obsolescence of the entire industry, the once dominant core location's market, and in turn economy, contracts. Thus, locations that house these industries face eventual instability in a capitalist economy.

Institutions and their geography play an important role within this model of geographical industrialization, although this is dealt with rather implicitly, neglecting the role of untraded interdependencies (Storper 1995). One of the primary resources of the locations which house the novel industry is their institutional flexibility, at least regarding how the new industry should be structured. Likewise, the region's accumulated institutions guiding capital accumulation become one of its primary resources. Finally, declining locations do so precisely because agents there are too habituated to the once successful system of conventions (e.g. 
Grabher 1993b). This habituation prevents them from seeing new opportunities for growth. Agents in other peripheral locales, however, do see and exploit these opportunities.

Storper, and Walker's (1989) model seems to work well in describing the process through which fairly novel or radical products (e.g. automobiles, agricultural equipment, aircraft, semi-conductors) come to be produced in former backwaters. Cast in another light, this model describes how a sectoral crisis (i.e., the substitution of one set of commodities for another) transforms regional economic geographies.

However, we find that the model of geographical industrialization has some missing links and, therefore, needs to be extended in order to conceptualize regional development paths. These missing links can be well illustrated in the case of Leipzig. First, this model does not explain how regions appear to re-invent themselves. For instance, while the model might help us understand the expansion of novel forms of automobile production in Leipzig in the future, it tells us little about Leipzig's re-vitalized cultural economy. Second, it does not clearly articulate a connection between regional expansion and wider political crises; i.e., regional expansion following on the heels of non-sectoral crises.

We attribute both shortcomings to a general under-politicization of this model. Like most models in economic geography, it makes few references to the wider socio-political conditions underpinning capital accumulation. Therefore, we suggest a re-conceptualization of regional development in which a multiple-trajectory understanding of development is systematically combined with discontinuities through national ruptures. We contend that windows of locational opportunity (Scott, and Angel 1987), when combined with crises models outlined in regulation school tracts (Aglietta 1979; Lipietz 1987; Boyer 1988), provide an adequate conceptual tool for understanding Leipzig's decline and rebirth as a media hub. 


\section{National Ruptures and Regional Development Paths}

This section develops the foundations for a model that explains regional development as an evolutionary process, dependent on numerous local industries which vie for dominance, undergo crises or ruptures and, through the ensuing struggle after this calamity, shape the region's development path. In this context, we also introduce the concept of regional bundles and combine it with the cluster concept to examine the processes of overcoming structural crises..$^{5}$ Regional bundles are interpreted as localized clusters of dynamic interrelated networks of economic activities or more precisely those regional parts of these 'industry clusters', capable of shaping the regional development path. Further, the concept of re-bundling refers to the processes which take place when actors in a region recombine the assets at hand to stimulate new growth, overcome crisis and 'make a living'. This process also includes the mobilization of capital from external sources but it manifests itself at the local and regional level. This provides a conceptual framework used in the empirical part for understanding the emergence of Leipzig's new media industry out of institutions unaffiliated with the formerly dominant old media industry.

${ }^{5}$ Porter (1990) has also acknowledged the role of wars, natural disasters and other historical events in his work on industrial clusters. However, he does not treat such ruptures in much detail. Porter (1998:85) contends that clusters "can and do lose their competitive edge due to both external and internal forces. Technological discontinuities are perhaps the most significant of the external threats because they can neutralize many advantages simultaneously. A cluster's assets ... may all become irrelevant." This is about as much as he deals with crises and their consequences. Such events are primarily treated as external, historical chance events which threaten the competitive advantage of existing clusters. In contrast, we apply a different understanding of crises and ruptures in this paper which also deals with their economic and social consequences and those processes following a crisis. In the concept of re-bundling we focus on the processes of economic action and interaction which are necessary to recombine and reintegrate external and internal assets at the local and regional level (see also Bathelt, and Glückler 2002a; 2002b). 


\section{Conceptualization of Crisis in the Regulationist Approach}

The regulationist approach furnishes a conceptual framework describing how cybernetically-related, national institutional compromises reproduce society, forestall economic crises and mediate economic restructuring (Dunford 1990; Robles 1994). Institutions, including markets, link consumption and production (Boyer 1988; 1990). In turn, this links the long-run reproduction of labor and capital to a national institutional framework (Lipietz 1987; Jessop 1992; Boggs 1997; Bathelt 1997; Barnes 1997). The central question of this framework is understanding what causes the variability of economic and social dynamics in time and space.

Regulation theorists approach this question by analyzing the nationally-specific mode of development which results from a particular regime of accumulation and mode of regulation (Lipietz 1987; Boyer 1990). However, the institutions of a particular mode of development do not always ensure expanded reproduction. Within a dynamic economy, ensembles of institutions that once stabilized capital accumulation can later fail (Jessop 1992; Barnes 1997). This results in changing economic, demographic, environmental, technological, sociological and geo-political conditions and undermines the ability of interacting individuals and organizations to maintain social compromises. When this 'mis-regulation' (Boggs 1997) persists, a crisis results.

\section{Boyer's Typology of Crises}

Boyer (1990:48-60) suggests a typology of five crises. These originate in particular analytical levels within a mode of development. The roots and severity of a particular crisis depend to a large part on geo-historical circumstances (see also Lipietz 1987; Hirsch 1990; Bathelt 1997; Barnes 1997; Boggs 1997).

Although all five forms of crises are relevant for our argument, we focus on two since they are most relevant for understanding the case of Leipzig. The first type of crisis originates 
outside of the national economy. Such crises are "episodes during which the continued economic reproduction of a given geographic entity is blocked, either due to shortages linked to natural or climactic disasters, or to an economic collapse originating in external events or wars" (Boyer 1990:49); and fit our empirical case. The second crisis type is that of the dominant mode of production in a society. Boyer (1990) designates it as a collapse of the fundamental social relations specific to a mode of production. Rooted in contradictions within the mode of development, such a crisis is the most profound and is recognized by the elimination of the 'rules of the game' and radical socio-political change.

Especially these two forms of crises have shaped Leipzig's economic development path throughout the 20th century. However, these are crises at the national, not the regional scale. We have yet to clarify how national crises affect regional structures and development patterns and what kind of ruptures take place within the institutional compromises at a regional level. From this, we suggest that crises can lead to a recombination of local assets which can, in turn, stimulate the creation of new capabilities.

\section{The Movement from Crisis to Stability}

Regulation scholars adamantly argue that balanced reproduction does not magically follow a crisis (Aglietta 1979; Lipietz 1987; Boyer 1990; 2000; Hirsch 1990; Jessop 1992). Instead, they contend that crises are only overcome through institutional and organizational experimentation. Through these experiments, actors within the economy attempt to restore conditions favorable for further capital accumulation. These ensembles are generated piecewise through political struggles and provisional compromises. Often the institutional logic and social norms arising from these struggles and compromises are not internally consistent but instead are partially contradictory (Kenney, and Florida 1989). These internal contradictions provide the seeds of future crises. 
Hirsch (1990), Boyer (1990:32) and Peet (1991) note that at any time in a society, secondary models of development co-exist with the established mode. During crises, some of these secondary models, previously seen as untenable by actors within the system, are viewed and implemented as possible means for securing stability. From these experiments and struggles, new compromises may eventually result. These compromises legitimize society's winners and losers; that is, particular sectors, technologies, creeds, ideologies, classes and ethnicities, all of which possess a geography. Some marginal groups under previous compromises and their regions become privileged in the current compromise. Likewise, some previously dominant groups and their regions find themselves marginalized. Crises, depending on their severity, annihilate bases of power while also opening up new opportunities by 'leveling the playing field'. This does not just refer to the devalorization of physical and financial capital, but also relates to human and social capital, collectively curtailing interactive learning (Bathelt 1997; Boggs 1997; Boggs, and Knudsen 1996).

These structural crises (i.e., the whole class of crises described by the regulation school) open up windows of locational opportunity (Storper, and Walker 1989; Bathelt 1997; Boggs 2001). However, instead of being driven by purely technological change, they originate in or are inter-penetrated by additional institutional transformations. Thus, crises may not just create growth opportunities in the capitalist national periphery, but also within the previously dominant regions. This conceptualization of windows of locational opportunity also resonates with Scott's (1988a; 1988b) model of new industrial spaces, in which crises pave the way for local re-development.

\section{Ruptures in Interactive Learning and Regional Development Paths}

Political and sectoral/ technological crises strain a regional economy's social cohesion: Unemployment increases, wages fall, social disparities widen and the potential for conflict increases. At the same time, however, structural changes may provide fresh opportunities for 
growth within the region. Crises disrupt existing transactional networks, releasing resources for alternative uses. Crises lead to two kinds of adjustments: (i) geographical shifts, as assets leave the region; and (ii) sectoral/ technological shifts, as assets are deployed within the region to its other sectors and technologies. Through sectoral/ technological shifts, innovations and talents developed in one sector filter into another.

Crisis does not automatically re-invigorate a region's subsidiary sectors. Dominant sectors, even in crisis, can still block the restructuring of their region's development path. Grabher (1993b) makes exactly this point, noting how the metal industry in the German Ruhr area formerly had the ear of local policy-makers. The iron and steel companies were thus able to shape training programs, demand sector-specific infrastructure and establish particular wage-labor relations, all of which blocked the entry of firms from other sectors.

However, as a sector undergoes a sectoral/ technological or political crisis, its affiliated assets lose value. This leaves policy-makers, workers and entrepreneurs no other choice but to languish, move away, develop new ventures or restructure existing firms. As actors within an affected region search for new markets and new jobs, they employ their capacity for interactive learning. Regionally, while the crisis has shattered the grip of the previously dominant sector, destroyed institutions regulating geographically specific forms of capital accumulation and thrown many out of work, people and firms can still deploy their competencies to find a new path towards prosperity.

\section{Re-bundling the Regional Development Path}

Recovery begins when agents re-bundle the capital at hand (i.e. financial, physical, human and social capital) for a new round of accumulation. Even if a given bundle of capital earns negative financial returns, agents still learn from this failure. Failure eliminates contextspecific dead-ends. Thus, interactive learning through systematic and trivial observation, information exchange, feedback, imitation, experimentation and other reflexive social practices 
enables the region's actors to re-bundle technological trajectories. Sometimes this becomes a new industry cluster, in turn promoting a new regional development path. Likewise, interactive learning also re-configures old specializations. Existing agglomerations take on new life; new agglomerations may form. Not every new bundle of technologies and related economic activities will, however, have a significant impact on a region's development. In order to shape a region's development path so that crisis is eventually overcome, a new ensemble of competencies must develop. While a branch plant economy can stabilize a regional development path, those regions housing the branch plants depend on technologies and decisions made elsewhere. Therefore, re-bundling is not just a local process, involving local assets. It also depends on external capital. For sustained growth, a cluster must, however, also be anchored into the local economy by non-ubiquitous resources found within a specialized social division of labor; it must have a certain minimum size; it must develop particular institutions to reproduce itself; and it must access markets and internalize novel inputs, partially located outside the region.

Maskell (2001), Malmberg, and Maskell (2002) and others have contributed to a more nuanced understanding of the processes driving the evolution of a regional cluster (Bathelt 2001a; 2002; Bathelt, and Glückler 2002a; Feldman 2001; Cooke 1999; Cooke, and Huggins 2001; Clark, Tracey, and Lawton Smith 2001) than that provided by the early Porter (1990) or his subsequent extensions (e.g. Porter 1998; 2000). This nuanced literature divides clusters along their vertical and horizontal dimensions. The vertical dimension consists of complementary firms, such as a network of supplier, service and customer relations. Marshall (1920) contends that successful ideas in firms spawn subsidiary trades in their neighborhood. Once a specialized cluster of activities exists, this creates incentives for other suppliers and customers to move to this cluster. This process forms a localized value chain or parts of it. New firms starting up in this cluster gain access to economies of scale and minimize transaction and other costs (Scott 1988a; 1988b; Krugman 2000). Equally if not more important than 
lower production costs are opportunities for interactive learning through information sharing, technological spillovers and intensive inter-firm communication (Lundvall 1988; Gertler 1993; 2001; Storper 1997; Maskell, and Malmberg 1999). Through this interaction, agents evolve a particular structure of social relations (Granovetter 1985) which affect their decision-making processes.

While often overlooked in studies of regional networks, the horizontal dimension is as important as the vertical (Maskell 2001; Malmberg, and Maskell 2002). The horizontal dimension refers to relations between a firm and its direct competitors. While rivalry might prevent them from closely cooperating or directly sharing knowledge, it does stimulate product differentiation and increased efficiency. Strong inter-firm rivalry serves to accelerate innovation and increase competitiveness (Porter 1990). ${ }^{6}$ The better the performance of a region's competitors in external markets, the stronger the incentives for specialized suppliers and service providers to relocate branch facilities to this region. Likewise, these competitive regions house more spin-off and start-up firms (Feldman 2001). A region's horizontal and vertical dimensions are strongly shaped by existing power relations, which impact the agents' ability to react to changes in their regulatory environment and external markets (Clegg 1989; Allen 1997; Taylor 2000).

In order to support the re-bundling process, new institutions must be created. Longterm growth depends on institutions that encourage inter-firm cooperation and collaboration towards coherent projects (Maskell 2001; Bathelt 2002). Institutions, such as particular norms, rules, habits and conventions, do not exist a priori but instead are constantly revised through

\footnotetext{
${ }^{6}$ We are aware, however, that innovativeness does not always imply competitiveness. Power, and Hallencreutz (2002) use the example of the Jamaican music industry to demonstrate that innovations do not necessarily result in higher profits. In the case of Jamaica, institutional barriers in some areas, combined with a lack of institutions in others, has resulted in an outflow of profits to other countries. Only clusters which are welldeveloped along their multiple dimensions secure a basis for regional actors to participate in the dynamic process of wealth-creation.
} 
social practice. Institutions make the actions of others more predictable because they reduce uncertainty in economic transactions (North 1990). Without institutions, mutual communication and collective learning are impossible; without these, a division of labor is impossible (Hodgson 1988). In a local context, policy intervention can support the development of an ensemble of institutions that may foster interactive learning. Such interventions might include restructuring the region's educational programs, establishing research centers and funding business incubators, each designed in a particular way to establish institutional thickness (Amin, and Thrift 1995) and satisfy the needs of the newly developing cluster. Within a region, these policies foster a specialized skill base, accelerate new firm formation and introduce new technologies. Most importantly, such interventions can encourage communication between the local actors.

Interactive learning does not happen in isolation. It depends on information about external markets and technologies (Bathelt 2001a; Bathelt, and Glückler 2002a). If internal linkages are too exclusive and too rigid, such social relations threaten the competitiveness of a firm or a whole group of firms (Uzzi 1997; Bathelt 2002). As emphasized by the milieu school, agents must establish linkages with external information sources or else they know nothing about relevant market trends and new technologies (Bramanti, and Ratti 1997; Maillat 1998). The local innovative successes of agents depends not only on internal or local assets, but also on external resources (e.g. Scott 1998).

\section{Sorting the Bundles}

An industry cluster's particular configuration shapes regional development paths. We use a conceptualization similar to that of Clark, Tracey, and Lawton Smith (2001) to develop a model of regional inheritance which provides a basis to characterize configurations of clusters. This in turn allows us to distinguish four general categories of regional bundles, those activities of an industry cluster located in the region. 
Clark, Tracey, and Lawton Smith (2001) suggest that regional development paths develop within the context of family and community inheritance. The inheritances include institutions and routines at different scales that support interactive learning. Family inheritance refers to the regional firms' accumulated individual capabilities. In our interpretation, we use family inheritance to describe the overall capability for internal or within-firm interactive learning of all firms in that region. In contrast, community inheritance is the overall capability for external or between-firm interactive learning. Community inheritance also creates an environment within which firms develop (i.e., it either does or does not help them learn from each other). In the short run, both inheritances are more-or-less fixed and unchangeable by individual actors. This combination of regional and firm inheritances determines whether or not a cluster emerges in a region and in turn shapes regional prosperity. Constructing a simple dichotomy of positive and negative inheritances from this framework reveals four cases (Table 1). Furthermore, we can place a region's industries or technological trajectories at any one time in one of these four boxes, even though they may not be anchored in a 'true' industry cluster.

CASE 1 is the most promising situation for a regional cluster since it combines positive characteristics of individual and networked capabilities. Thus, the CASE 1 cluster has potential to grow substantially and shape a region's development path. In contrast, CASE 4 is particularly problematic since both inheritances are negative. In this case, individual firms do not foster internal interactive learning, nor is the community supportive of interactive learning between its members. Not only can firms not learn from each other, but they are also unlikely to learn about regions elsewhere with positive community characteristics (i.e. supportive of interactive learning). This means a given firm is unable to make an informed decision about relocation to a better environment elsewhere (Clark, Tracey, and Lawton Smith 2001). In CASE 2, the community networks foster active learning between firms and thus might be strong enough to either jump-start learning within firms or allow them to free-ride off of the 
community. Such a case might exist where there is labor-market pooling, but firms are branch plants with little desire or ability to deviate from the corporate headquarters' orders. In CASE 3, future development patterns are much less clear. Corresponding firms have internalized interactive learning capabilities, but the community does not foster interactive learning between its members. Regional development paths might here be dominated by a few large firms in an industry which then dictate terms to their suppliers. On the one hand, the firms may just consume their existing assets. This eventually leads to CASE 4. On the other hand, they might recognize the futility of remaining in place and relocate to a community that fosters interactive learning, resulting in a CASE 1 situation elsewhere.

Only in CASE 1 can we assume that a regional bundle emerges which clearly shapes the regional development path. While CASE 2 has potential to develop such an impact in the medium-run, CASE 3 and CASE 4 have no such potential unless substantial external help is provided. The decision to establish a public television and broadcasting station in Leipzig is an external trigger driving the regional re-bundling process. This also underlines another claim we wish to emphasize, namely that development paths are contingent and can fundamentally change in the long-run or even medium-run.

We argue that Leipzig's pre-Reunification book-trade was a CASE 1 configuration at that time, characterized by a combination of outstanding overall community and firm capabilities in this industry. The region had excellent potential for further agglomerated growth. Due to the economic and societal ruptures after World War II and German Reunification in 1990, this situation changed dramatically. The new cluster of media industries began to develop in a badly equipped regional environment with fairly inexperienced, technologically limited firms. Since then, community capabilities have improved due to the establishment of some institutional infrastructure. However, networks between local firms are still not that extensive. 


\section{Summary: Towards a Re-conceptualization of Regional Development Paths}

Knowledge production and application through interactive learning drives growth in our model. As such, this deviates little from previous observations made in evolutionary economics. Interactive learning is a context-dependent, social process through which people learn from each other. Furthermore, this context takes on a social and/ or geographical bias, slowing down or even preventing the diffusion of this knowledge outside of this context. Colocation provides one necessary, but not in and of itself sufficient, pre-requisite for some forms of interactive learning dependent on tacit and contextualized codified knowledge. This context, built up by knowledge and heuristics gleaned through interactive learning, structures the evolution of a technology. At the same time, each technological trajectory is contingent, dependent on the interaction of imperfectly informed actors who stumble into a dimly lit future.

Much of the technological trajectory literature and its application in economic geography favor technological continuity and tend to neglect ruptures. While Arthur's (1988) model of path dependence tells us why technological continuity exists, it provides no explanation for technological ruptures. Although early events certainly are important in establishing a technological trajectory, they do not ensure its continuation. Lock-in results from repeated interactive learning along a technological trajectory; if this does not continue, the technological trajectory falters.

A faltering technological trajectory, however, does not necessarily mean the collapse of a region. Most regions are not technologically homogenous, but instead contain bundles of overlapping technological trajectories. The interplay of these bundled technological trajectories unfolds into a regional development path. A crisis or rupture within one technological trajectory may or may not cause a major sectoral crisis in a given region; this depends upon the importance of that technological trajectory to the given region. But crises arise outside of purely technological reasons as well. 
Political crises can undermine the institutions which ensure medium- and long-term macroeconomic growth. Finding a solution to a particular crisis (i.e., developing institutions that ensure medium- and long-term growth) requires interactive learning. Thus, interactive learning is not only concerned with creating technological and organizational innovations of a radical or incremental nature, but of also creating wider institutions that circulate capital in all its forms (i.e. human, financial, cultural, physical, social). Thus regional development paths take place within a wider social context. Within a given region, these changed conditions (i.e., this national rupture) provide windows of opportunity for previously marginal as well as novel industries. In the process of adapting to this rupture, local agents in these marginal or novel industries re-bundle local resources; this in turn shapes the new regional development path. In some cases, these re-bundled resources form a tightly linked industry cluster in the region that impacts or even dominates the regional economy and the region's development path, at least until upended by the next sectoral/ technological or political crisis.

\section{Continuity and Rupture in Leipzig's Development Path}

Since the mid and late 1990s, local politicians and planners point out the importance of Leipzig (Figure 1) as 'the city of media'. They frequently draw direct parallels between the city's pre-War tradition in book publishing and the now growing cluster of activities in TV/ film production and new digital media. This development is implicitly presented as one of continuity claiming that the region has a long history of competence in media industries. According to this, Leipzig appears to be the site of a durable cultural economy. In recent years, claims of continuity in Leipzig's media history have spilled over into academic work. This is exemplified in the work of v. d. Berg et al. (2001:99) who emphasize that "Leipzig has long been a media city of considerable importance. ... Currently, the city of Leipzig aims at revitalizing its media past by building a new media future... ." The following examination calls into question this claim of continuity. Furthermore, we do so making use of the conceptual 
framework introduced in the previous sections. We particularly investigate the effects of political crises and regional re-bundling on Leipzig's historical evolution.

\section{Centuries of Continuity: The Evolution of Leipzig's Book Publishing Industry Until 1945}

Leipzig continuously housed a dynamic book publishing industry for centuries. The first recorded book printer-publisher set up a shop in Leipzig around 1481, roughly 30 years after Gutenberg's invention of the moveable-type printing press (Menz 1942; Schulz 1989; Schönstedt 1991). While paper manufacturers, rag millers, page illustrators and book binders already supplied Medieval scribes with their requisite inputs, the printing press' diffusion transformed the Central European economic geography of publishing. Books were now produced on a speculative basis instead of handcrafted for an individual patron, as had been the case amongst monasteries. Printers' apprentices sought out new urban markets, transforming the geography of knowledge-production and dissemination as well as local economies. These printers knitted together existing traditional suppliers to the printing trade as well as eventually created demand for new suppliers such as type-casters and press manufacturers. In turn, this bundling of local and regional assets reverberated throughout Europe's urban division of labor. As a result, Leipzig, which had developed into an important trading and population

center in the late Middle Ages, became one of Central Europe's earliest book publishing sites (Schulz 1989; Wittmann 1999). For book production, Leipzig's locational advantages included not only its central position in the European trading network; i.e., being located at the intersection of major trade routes (Gormsen 1996), but also its cultural proximity to the Protestant Reformation. While the Reformation embodied a crisis which rocked the precapitalist European social and economic order, this crisis also provided a window of opportunity for Leipzig, which became an important site of Reformation printing after Luther's death in the early 1500s (v. Schroeder 1904/1970). 
While Leipzig's book fairs were far friendlier than Frankfurt's (here and in the following section, we refer to Frankfurt/ Main) to Reformationist and other heretical works, it also attracted a different segment of book traders. In the long-run, this differentiation worked to Leipzig's advantage. Frankfurt's book fair drew an international crowd of publishers, with Latin texts dominating. Leipzig, even while attracting foreign publishers, catered to increasingly more German dialect texts. As demand for Latin texts declined and demand for German texts rose through the next few centuries, Leipzig grew in importance. Furthermore, beginning in the 16th century, Leipzig's printer-publishers benchmarked their books' quality against that of Dutch printers in an effort to produce the most physically attractive books. This early example of learning-through-competition did not catch on in Frankfurt, which was increasingly inundated with poorly printed, low-quality books (v. Schroeder 1904/1970; Menz 1942; Schulz 1989; Wittmann 1999).

Leipzig's dominance was secured in 1710, when Frankfurt's book fair commission rescheduled its spring session to take place eight days after the Leipzig Easter book fair. This decision was fateful since the book traders had to make their choice to either attend in Frankfurt or Leipzig. Most book traders elected to attend the already more important Leipzig fair. As a result of this political decision, the Frankfurt book fair lost its importance and closed down in 1764, not to reopen again until 1949 (v. Schroeder 1904/1970; Menz 1942; Schulz 1989; Wittmann 1999).

By the late 18th century, Leipzig housed numerous firms operating in narrow niche markets. These publishers and subsidiary trades further specialized and concentrated in Leipzig's Graphisches Viertel. This geographical concentration developed into a 'true' Marshallian industrial district (Boggs 2001), forming a growing regional bundle of interrelated industrial activities. This bundle consisted of a large number of competitive, as well as complementary, trades and was well-connected with interregional and international markets. 
Numerous institutional innovations further shaped and strengthened the industry. The first was the formation of a centralized exchange for settling accounts during and between book fairs. This innovation reduced the time needed to track down overdue accounts and identify delinquents, leaving publishers more time for networking and salesmanship during the trade fairs. While started as a private firm, in 1825 this organization was eventually converted into a member-run industry organization, the Börsenverein des Deutschen Buchhandels ('German Publishers and Booksellers Association'). Its members hailed from across German-speaking Europe, and not just Leipzig. The second institutional innovation, the Leipziger Bestellanstalt, a clearinghouse for book orders, opened in 1842. Through this, book orders were processed faster, with fewer mistakes and delivered in bulk; all of which reduced expenses (v. Schroeder 1904/1970; Menz 1942; Schulz 1989; Wittmann 1999).

Leipzig developed into and remained a powerful agglomeration for centuries. In 1938, it housed over 300 book publishers and 500 allied firms (Figure 2), as well as the German equivalent of the U.S. Library of Congress, the Deutsche Bücherei (Adressbücher Redaktion des Börsenvereins des Deutschen Buchhandels zu Leipzig 1938; Menz 1942). This industry cluster was characterized by strong vertical, horizontal, institutional and external dimensions, enabling it to continue to grow its production and distribution network. Overall, book trade and publishing developed into an important regional bundle which stamped Leipzig's overall regional development path until the Second World War.

\section{Regional Rupture I and Its Consequences: Leipzig's Book Publishing Industry in the} G.D.R.

While Berlin eventually housed more publishers, Leipzig still maintained its dominance up until the Second World War. However, by the mid 1940s, Leipzig's and Berlin's publishing industries lay in ruins. Air raids destroyed fully $80 \%$ of their physical plants; wartime planning shunted skilled labor into other crucial industries; and fascist censorship and 
cultural policy had replaced the city's former liberal traditions. For Leipzig's book publishing industry, this social, political and economic crisis initiated a regional crisis that continued well past the Second World War, as Soviet demontage-as-repatriation, G.D.R. (German Democratic Republic) nationalization, further censorship and U.S. attempts to attract skilled talent to the U.S. zone drove more of the industry's remaining skilled workers away from Leipzig. Overall, this dramatically ruptured the evolution of the local media sector, as well as other industries in Leipzig. While the Graphisches Viertel was rebuilt following the Second World War, it was integrated into the international socialist division of labor and interacted little with West Germany.

The city's former western market was now split between publishers in Munich, West Berlin, Hamburg, Stuttgart, Frankfurt and Cologne. This re-bundling in West Germany included a relocation of the industry's institutions from Leipzig. A new branch of the Börsenverein was established in Frankfurt. Likewise, Frankfurt resurrected its book fair after a nearly 200 year hiatus. In addition, the Deutsche Bibliothek (German National Library), the western equivalent of Leipzig's Deutsche Bücherei, was built in Frankfurt. Through this reorganization, Leipzig's publishers lost much of their importance for West German and other West European book markets.

By 1989, Leipzig's publishing industry had been vertically integrated into just 36 VEB (Volkseigene Betriebe; or people's own enterprises). Its workforce knew little of western business practices and operated with aged equipment. While propagandized as 'Leseland DDR' (The German Democratic Republic - Land of Reading), many of its consumers were a captive audience and the VEB developed little marketing knowledge. Interactive learning in this context indeed developed, but was directed at dealing with problems endemic to Sovietstyle planned economies. Even though Leipzig was still an important location of the printing and publishing industry in the G.D.R., it lost some of its status as an international center of these industries. With German Reunification, Leipzig's book publishing industry was poorly 
equipped for integration into the larger West German economy (Karrasch 1989; Volpers 1991; Gormsen 1996; Wittmann 1999; Boggs 2001). Forced integration of the various trades in the book publishing industry had resulted in state-controlled business patterns, blocking off any sort of market-led competition. The horizontal and vertical dimension of this pre-War industry cluster underwent far-reaching transformations which worked against Leipzig. Without interaction, the traditional institutional structure continuously eroded and connections with western markets withered. As a consequence, Leipzig's book publishing industry lost its importance as a regional bundle and was unable to shape Leipzig's regional development path.

\section{Regional Rupture II and Its Consequences: Initial Attempts of Re-constructing Leipzig as a Media City After German Reunification}

At the time of German Reunification in 1990, Leipzig's book publishing industry, like most industries in the former G.D.R., was not well positioned for market-driven competition. Leipzig experienced a new regional rupture related to the breakdown of its state-planned economy. At the same time, Leipzig's politicians, city officials and some of the book publishers saw in Reunification an opportunity to re-capture the city's former importance. In 1990, the Förderverein Medienstadt Leipzig (Development Association of the Media City Leipzig), a loosely organized public-private partnership, began agitating for re-development of the Graphisches Viertel as a site of book publishing and affiliated industries (Schubert 2000). The Förderverein coordinated public activities and promoted the vision of Leipzig as a media city through a dense network of media-related businesses and institutions. A program was suggested in which goals for future developments were outlined (Baier 1992). The Förderverein's primary vision was to resurrect Leipzig's tradition as one of the major centers of book publishing in Germany.

The traditional location of print media in the Graphisches Viertel was supposed to develop into the center of Leipzig's re-invigorated media sector. However, in the 45 years since 
Germany's division a highly contested book publishing landscape had evolved in the western part of the country, essentially locking out uncompetitive Leipzig (Boggs 2001). Not only did calls to relocate the western part of the Börsenverein to Leipzig fall on deaf ears (Kahlefendt 2000), but also Leipzig's book fair did not regain its international importance. Furthermore, Leipzig's publishing houses did not flourish and instead scaled back employment and output. New western owners often left only a skeleton staff to run boutique publishing houses. Book publishing thus underwent massive de-industrialization (Volpers 1991; Lemke 1992;

Börsenblatt 1993; Bach 1995; Denzer, and Grundmann 1999; Wittmann 1999; Boggs 2001; v. d. Berg et al. 2001). This second crisis had strong effects on unemployment and social welfare in the region throughout the 1990s. It took several years until political programs and market forces were able to initiate some re-bundling activities within the city.

\section{Re-bundling a New Regional Development Path: Leipzig's Creative Media Industries Since the Mid 1990s}

The formation of a new media cluster in Leipzig during the 1990s did not develop out of the former book publishing industry. The recent growth of the media industry is neither embedded in book publishing's traditional industrial structures and institutional settings, nor in its former industrial district of the Graphical Quarter (Figure 3). Instead, local agents began re-bundling local assets left in the aftermath of drastic ruptures in the region's development path. Leipzig's cluster of firms in TV/ film production and new digital media has yet to develop into a dynamic regional bundle and thus does not have the same importance for the regional economy as did the former book publishing industry.

While the anemic Graphisches Viertel, recipient of substantial re-development funds, sheltered only a small number of book publishers in the late 1990s, Leipzig-Connewitz on the city's southern edge housed a growing new media industry centered around MDR (Mitteldeutscher Rundfunk; or Middle German Broadcasting Service), a public television and 
broadcasting network (Denzer, and Grundmann 1999). But why Leipzig at all? In the area of electronic media, such as the television and film industry, Leipzig had never played an important role (Sagurna 2000). The G.D.R. television and film sector, characterized by a rigid hierarchical organization, was concentrated in East Berlin and nearby Potsdam, with some regional activities in Dresden and only a small studio in Leipzig. This is still visible today, providing the economic base that allows Potsdam-Babelsberg to develop into an important center of the German film industry (Gräf 2001; Krätke, and Scheuplein 2001).

The decision to establish MDR in Leipzig was due, in part, to Leipzig's physical location in the center of southeastern Germany, historically known as Middle Germany. An interview in 2000 with the Saxon media representative, Mr. Sagurna, revealed that this decision was a political compromise between the three Länder (German states) involved: Saxony, Saxony-Anhalt and Thuringia. Due to its central location, Leipzig was the only city in Saxony which would be readily accepted by politicians from Saxony-Anhalt and Thuringia since it is located close to both Länder (Figure 1). In theory, all Länder benefit from media-related economic growth emanating from Leipzig.

The reasons of MDR for selecting Leipzig, as well as its location in Leipzig, provide evidence that this creative industry cluster is indeed a new development and not deeply embedded in the institutions underpinning book publishing (Bathelt 2002). This is not to say there are absolutely no connections with this past media sector. Universities and technical schools, such as the Hochschule für Graphik und Buchkunst (College for Book and Graphic Arts), originally affiliated with book publishing have added programs training workers for Leipzig's new media industries and creating specialized skills in media professions (Sagurna 2000; Bathelt 2001a). The formation of this cluster has, however, not resulted from a renewal of pre-existing industries. It is not embedded in historical structures and traditional social relations. 
Instead, Leipzig's new media industry has primarily grown out of local start-ups and branch facilities which serve MDR (Bathelt 2001a; v. d. Berg et al. 2001). These firms are inter-connected with one another and, in particular, with the region's most important actors (i.e. MDR and the new Leipzig convention center). Through this, especially the vertical dimension of this developing bundle has grown substantially. The media firms benefit from localized capabilities, such as the development of particular institutional structures, a regional customer basis, local labor market relations and a distinct local identity. Leipzig's new media industry has formed largely to serve MDR but its existence is also related to other processes. The Leipzig media economy spans a number of creative activities, such as graphics, design, internet services, marketing, public relations, theatre and music, none of which are closely related to MDR (Bentele et al. 1998; 2000). In addition, the new media cluster is apparently not the result of some pre-existing political master plan at the local or regional scale.

Interviews with MDR representatives and local experts have provided evidence that this growth also reflects MDR's strategy to spin out its functions into separate subsidiaries and subcontract other functions to local suppliers and services. The goal behind this strategy was to establish a local supply and support sector for television and film production while reducing costs. To accomplish this, suppliers and service providers from other regions were required to establish branches in Leipzig or relocate their offices to the area to keep their contracts. As a result of this policy, MDR is no longer forced to rely on contractors located in different regions. This has, in turn, stimulated start-up and relocation activities.

Despite Leipzig's lack of television and film resources, a new media cluster developed in the city during the 1990s around the activities of MDR. According to a survey of Bentele et al. (1998), this TV/ film production and new digital media cluster had about 8,000 permanent employees in several hundred firms in 1998 (not including the thousands of freelance consultants). With its establishment, MDR rapidly became the most important anchor organization in supporting the establishment of television- and film-related media branches in 
Leipzig (Sagurna 2000; Schubert 2000; Bathelt 2001a). The media industry is one of the few economic sectors which have experienced economic growth in the post-Reunification period and helps stabilize Leipzig's economy. Spurred by MDR's need for local suppliers, thanks in part to MDR's local-content regulations, we observe a re-bundling of Leipzig's local assets through interactive learning. Given that most of the G.D.R.'s formal institutions did not survive Reunification, where then are the assets which have become the basis for this local rebundling?

New firm formation is the site of re-bundling. Bentele et al. (2000) found that $84 \%$ of the firms included in their survey were founded within the Leipzig region. According to interviews conducted by Bathelt (2001a; 2002), these firms were established by people born in Leipzig, or by people who had studied or worked in Leipzig for many years. Many of these entrepreneurs felt an attachment to Leipzig that went beyond the purely economic. One founder indicated that Leipzig was the place of choice in establishing his firm because of "the feeling the city had to it". For most entrepreneurs interviewed, there was no question of locating elsewhere. In general, start-up decisions are influenced by the experience a founder has accumulated while working in a particular technological field or during his training in a specialized work area (e.g. Hayter 1997). This has also been the case in Leipzig.

Interviews with managers of branch facilities suggest that decisions to locate in Leipzig were based primarily on profitability and proximity to MDR. These MDR-related establishments and privatizations of former VEB spurred local growth in the media industry. Employees from the former G.D.R. television and film industry reported skepticism about working for people from West Germany. Rather than looking for a media job in a West German firm they preferred to establish their own business with those they already knew through work (Bathelt 2001a). For these people, Leipzig was the city of choice because of the opportunities related to MDR. Another group of firms in the West German television and film business established branches in Leipzig or relocated part of their activities to the region to 
acquire contracts from and offer services to MDR (Bathelt 2001a). In some cases, MDR asked professional film teams, technicians, cutters, reporters, news agencies and other media specialists from other regions to establish a branch in Leipzig and offered future contracts to attract specialized firms.

These 'transplants' played an important role in the development of the media industry since they brought professional expertise and specialized experience into the region which did not exist previously. Due to the combined effects of MDR and the TV/ film production and other creative media activities, a network of specialized activities and competencies developed which became an incentive for euphoric local start-ups and university spin-offs (Bathelt 2001a; 2002; Figure 4). The new institutional structure supports this growth (v. d. Berg et al. 2001). Graduates from special training programs and institutions of higher learning, such as the Hochschule für Technik, Wirtschaft und Kultur (College for Technical, Economic and Cultural Studies), establish a basis for further firm formation which is, in turn, supported by start-up consulting and financial funds providing start-up money. Overall, a regional network of institutional support is beginning to develop which provides a distinct institutional thickness (Amin, and Thrift 1995). This is likely to drive future start-up activities in creative media industries.

In contrast with the growing vertical cluster dimension, which has benefited from start-up processes and vertical disintegration tendencies of MDR, the horizontal dimension of this regional bundle is still underdeveloped. There is clearly a lack of independent television and film production companies. Local competition is also weak in the area of sophisticated supplies which require substantial producer-user interaction. At this point the growth process is thus still in an infant stage and the cluster of media activities has not yet fully unfolded its vertical and horizontal structure, supporting institutions and linkages with external growth markets (Bathelt 2002). In order to develop into an important regional bundle driving the re- 
gional development path in the future, conditions will have to develop which allow for a deepening of the social division of labor and induce on-going regional growth.

\section{Summary}

Leipzig was one of the earliest book publishing hubs in both Germany and Central Europe. Holding this position for many centuries, its dense network of publishers, printers, papermakers and wholesalers was woven into an institutional fabric, knitting together German-speaking Europe. We contend that interactive learning anchored book publishing in Leipzig. The Second World War reduced this once vibrant industrial district, and its localization effects, to ruins. While its remaining assets were diligently re-bundled, it never re-gained its place within the German book publishing landscape. Although integrated into the international socialist division of labor, Leipzig's state-owned publishers were ill-suited to survive German Reunification, which brought massive restructuring in its wake. With this second crisis, locals attempted to use what they hoped was a window of locational opportunity and recapture the book industry's former glory by re-developing the city's Graphisches Viertel. These attempts largely failed.

However, a new TV/ film production and digital media cluster has emerged, centered around MDR. While not the largest such cluster in the country (Krätke, and Scheuplein 2001; Bathelt 2002), it nonetheless stimulates Leipzig's faltering economy. This transformation of Leipzig into a television broadcasting and digital media center is not a continuation of book publishing, but instead a rupture with its past assets. Use of insights gleaned from Clark, Tracey, and Lawton Smith (2001) allows us to categorize this rupture along two dimensions, as shown in Table 2. Leipzig's book trade up to the Second World War was a CASE 1 configuration, with its book publishing industry characterized by outstanding overall community and firm capabilities, clearly shaping the regional economy. The region had excellent potential for further agglomerated growth. However, due to post-Second World War economic and 
societal ruptures as well as German Reunification in 1990, Leipzig's book publishing was locked out of major German markets. While local actors tried to change this situation, they were not successful.

Despite this, a new TV/ film and digital media cluster began to develop as a result of an administrative choice to locate MDR in Leipzig. This was a poorly equipped regional environment for these media branches, populated with fairly inexperienced and technologically limited firms. Therefore it seems that any agglomeration economies here are primarily caused by urbanization effects, and not the localization effects that apparently once characterized the Graphisches Viertel (see also Capello 2001 for similar findings in a different context). However, community capabilities have improved due to the establishment of some institutional infrastructure. In turn, this might strengthen localization effects in the new media industries. However, networks between local firms are still not that extensive. At best, the present Leipzig media industry could be described as moving from CASE 4 to a CASE 2 or CASE 3, an environment in which firms have internalized interactive learning routines but the community does not (yet) foster interactive learning.

\section{Conclusion}

Evolutionary economics treats interactive learning as the primary causal mechanism driving growth and change. Likewise, interactive learning propels technological trajectories. However, regional development paths are not the spatial manifestations of a homogeneous technological trajectory. Instead, they consist of bundles of technological trajectories, some dominant, some operating on the region's periphery. These regional development paths are not continuous, but instead are punctuated by sectoral/ technological crises and political ruptures. Crises provide agents chances for interactive learning geared towards re-bundling local capital, spurring growth and change in formerly peripheral or entirely novel industries. This paper develops a conceptual framework incorporating these claims, and then uses this 
framework to analyze the demise of Leipzig's book publishing industry and the unrelated growth of its broadcasting, film and digital media industry. This is not to say that the importance of crises and their impacts in a regional development context is something totally new. We feel, however, that there is a tendency in recent work in economic geography and other social sciences to over-emphasize increasing returns and continuity while neglecting ruptures and discontinuities in the regional development context. Our emphasis of structural crises illustrates how Leipzig's pre-War and post-Reunification media industries are not extensions of the same regional development path or a continuous history as 'the city of media'. Instead, they are manifestations of different regional development paths.

\section{References}

Adressbücher Redaktion des Börsenvereins des Deutschen Buchhandels zu Leipzig 1938. Adressbuch des Deutschen Buchhandels 1939 (Directory of the German book trade 1939). Leipzig: Verlag des Börsenvereins des Deutschen Buchhandels zu Leipzig.

Aglietta, M. 1979. A theory of capitalist regulation: The US experience. London, New York: Verso.

Allen, J. 1997. Economies of power and space. In Geographies of economies, ed. R. Lee and J. Wills, 59-70. London: Arnold.

Amin, A., and Thrift, N. 1995. Living in the global. In Globalization, institutions, and regional development in Europe, ed. A. Amin and N. Thrift, 1-22. Oxford, New York: Oxford University Press.

Arrow, K. J. 1962. The economic implications of learning by doing. Review of Economic Studies 29:155-173.

Asheim, B. 1999. Interactive learning and localised knowledge in globalising learning economies. GeoJournal 49:345-352. 
Arthur, W. B. 1988. Competing technologies: An overview. In Technical change and economic theory, ed. G. Dosi, C. Freeman, R. R. Nelson, G. Silverberg and L. L. G. Soete, 590-607. London, New York: Pinter Publishers.

Bach, J. 1995. Was aus den DDR Verlagen geworden ist (What happened to the G.D.R. publishers). Frankfurter Allgemeine Zeitung 12 December.

Baier, H., ed. 1992. Medienstadt Leipzig: Tradition \& Perspektiven (Leipzig as a media city: Traditions and perspectives). Berlin: Vistas.

Barnes, T. J. 1997. Theories of accumulation and regulation: Bringing life back into economic geography. In Geographies of economies, ed. R. Lee and J. Wills, 231-247. London: Arnold.

Bathelt, H. 1997. Chemiestandort Deutschland. Technologischer Wandel, Arbeitsteilung und geographische Strukturen in der Chemischen Industrie (German chemical industry. Technological change, the division of labor and geographical structure). Berlin: Edition Sigma - Bohn.

Bathelt, H. 2001a. The rise of a new cultural products industry cluster in Germany: The case of the Leipzig media industry. IWSG Working Papers 06-2001 (Web Site: http://www.uni-frankfurt.de/fb11/wigeo/iwsg/iwsg.html). Frankfurt/ Main.

Bathelt, H. 2001b. Regional competence and economic recovery: Divergent growth paths in Boston's high technology economy. Entrepreneurship and Regional Development $13: 287-314$.

Bathelt, H. 2002. The re-emergence of a media industry cluster in Leipzig. In: European Planning Studies 10:583-611.

Bathelt, H., and Glückler, J. 2002a. Wirtschaftsgeographie: Ökonomische Beziehungen in räumlicher Perspektive (Economic geography: Economic relations in spatial perspective). Stuttgart: UTB - Ulmer. 
Bathelt, H., and Glückler, J. 2002b. Towards relational economic geography. Paper presented at the Annual Meeting of the Association of American Geographers, Los Angeles.

Belussi, F., and Gottardi, G., eds. 2000. Evolutionary patterns of local industrial systems. Aldershot: Ashgate.

Belussi, F., and Pilotti, L. 2001. Learning and innovation by networking within the Italian industrial districts: The development of an explorative analytical model. Paper presented at the Conference of the IGU Commission on the Dynamics of Economic Spaces, Turin.

Bentele, G.; Liebert, T.; and Polifke, M. 2000. Medienstandort Leipzig III: Eine Studie zur Leipziger Medienwirtschaft 2000 (Leipzig as a location of the media industry III: A study of Leipzig’s media economy 2000). Leipzig.

Bentele, G.; Polifke, M.; and Liebert, T. 1998. Medienstandort Leipzig II: Eine Studie zur Leipziger Medienwirtschaft 1998 (Leipzig as a location of the media industry II: A study of Leipzig’s media economy 1998). Leipzig.

Best, M. H. 2000. Silicon Valley and the resurgence of Route 128: Systems integration and regional innovation. In Regions, globalization and the knowledge-based economy, ed. J. H. Dunning, 459-484. Oxford: Oxford University Press.

Bluestone, B., and Harrison, B. 1982. The deindustrialization of America. New York: Basic Books.

Boggs, J. 1997. A regulationist analysis of the conditions preceding and following German Reunification. Unpublished Masters thesis. Bloomington (IN): Department of Geography, Indiana University.

Boggs, J. 2001. Path dependency and agglomeration in the German book publishing industry. Paper presented at the Annual Meeting of the Association of American Geographers, New York. 
Boggs, J. and Knudsen, D. 1996. The current transition in industrial capitalism. In The transition to flexibility, ed. D. C. Knudsen, 1-14. Boston, London, Dordrecht: Kluwer.

Börsenblatt 1993. Verlage der früheren DDR im Überblick: Übernahmen, Beteiligungen, Liquidationen (Publishers of the former G.D.R.: Mergers, acquisitions, closures). Börsenblatt 5 January, 53-54.

Boschma, R. A. 1997. New industries and windows of locational opportunity. A long-term analysis of Belgium. Erdkunde 51:1-19.

Boschma, R. A., and Lambooy, J. G. 1999. Evolutionary economics and economic geography. Journal of Evolutionary Economics 9:411-429.

Boyer, R. 1988. Technical change and the theory of 'régulation'. In Technical change and economic theory, ed. G. Dosi, C. Freeman, R. R. Nelson, G. Silverberg and L. L. G. Soete, 67-94. London, New York: Pinter.

Boyer, R. 1990. The regulation school: A critical introduction. New York: Columbia University Press.

Boyer, R. 2000. The political in the era of globalization and finance: Focus on some régulation school research. International Journal of Urban and Regional Research 24:274322.

Boyer, R., and Orléan, A. 1992. How do conventions evolve? Journal of Evolutionary Economics 2:165-177.

Bramanti, A., and Ratti, R. 1997. The multi-faced dimensions of local development. In The dynamics of innovative regions: The GREMI approach, ed. R. Ratti, A. Bramanti and R. Gordon, 3-44. Aldershot, Brookfield: Ashgate.

Cantwell, J., and Fai, F. 1999. Firms as the source of innovation and growth: The evolution of technological competence. Journal of Evolutionary Economics 9:331-366. 
Capello, R. 2001. Agglomeration economies and urban productivity: Urbanisation vs. localisation economies in the metropolitan area of Milan. Jahrbuch für Regionalwissenschaft 21:1-23.

Clark, G. L. 1986. Restructuring the US economy: The NLRB, the Saturn project, and economic justice. Economic Geography 62:289-306.

Clark, G. L. 1988. Corporate restructuring in the US steel industry: Adjustment strategies and local labor relations. In America’s new economic geography, ed. G. Sternlieb and J. Hughes, 179-214. New Brunswick, NJ: Center for Urban Policy and Research, Rutgers University.

Clark, G. L.; Tracey, P.; and Lawton Smith, H. 2001. Agents, endowments, and pathdependence: A model of multi-jurisdictional regional development. Geographische Zeitschrift 89:166-181.

Clegg, S. 1989. Frameworks of power. London: Sage.

Cooke, P. 1999. The co-operative advantage of regions. In The new industrial geography: Regions, regulation and institutions, ed. T. J. Barnes and M. S. Gertler, 54-73. London: Routledge.

Cooke, P., and Huggins, R. 2001. High-technology clustering in Cambridge (UK). Mimeo. Cardiff: Centre for Advanced Studies, Cardiff University; Newidiem.

Crewe, L. 1996. Material culture: Embedded firms, organizational networks and the local economic development in a fashion quarter. Regional Studies 30:257-272.

Denzer, V., and Grundmann, L. 1999. Das Graphische Viertel - ein citynahes Mischgebiet der Stadt Leipzig im Transformationsprozeß: Vom Druckgewerbe- zum Bürostandort (The transformation of Leipzig's Graphical Quarter: From printing and publishing to modern office functions). Europa Regional 7(3):37-50. 
Dosi, G. 1982. Technological paradigms and technological trajectories: A suggested reinterpretation of the determinants and directions of technical change. Research Policy 2:147-162.

Dosi, G. 1988. The nature of the innovative process. In Technical change and economic theory, ed. G. Dosi, C. Freeman, R. R. Nelson, G. Silverberg and L. L. G. Soete, 221-238. London, New York: Pinter.

Dunford, M. 1990. Theories of regulation. Environment and Planning D: Society and Space $8: 297-321$

Feldman, M. P. 2001. The entrepreneurial event revisited: Firm formation in a regional context. Industrial and Corporate Change 10:861-891.

Gertler, M. S. 1993. Implementing advanced manufacturing technologies in mature industrial regions: Towards a social model of technology production. Regional Studies 27:665680.

Gertler, M. S. 1996. Worlds apart: The changing market geography of the German machinery industry? Small Business Economics 8:87-106.

Gertler, M. S. 2001. Local knowledge: Tacitness and the geography of context. Paper presented at the Annual Meeting of the Association of American Geographers, New York.

Gormsen, N. 1996. Leipzig - Stadt, Handel, Messe: Die städtebauliche Entwicklung der Stadt Leipzig als Handels- und Messestadt (Leipzig's development as a trade and exhibition center). Leipzig: Institut für Länderkunde.

Grabher, G. 1993a. Rediscovering the social in the economics of interfirm relations. In The embedded firm. On the socioeconomics of industrial networks, ed. G. Grabher, 1-31. London, New York: Routledge.

Grabher, G. 1993b. The weakness of strong ties: The lock-in of regional development in the Ruhr area. In The embedded firm. On the socioeconomics of industrial networks, ed. G. Grabher, 255-277. London, New York: Routledge. 
Grabher, G. 2002. The project ecology of advertising: Tasks, talents and teams. Regional Studies 36:245-262.

Gräf, P. 2001. Das Buchverlagswesen und seine Standorte (The German book publishing industry). In Nationalatlas Bundesrepublik Deutschland: Band 9. Verkehr und Kommunikation, ed. Institut für Länderkunde, 116-117. Heidelberg, Berlin: Spektrum.

Granovetter, M. 1985. Economic action and economic structure: The problem of embeddedness. American Journal of Sociology 91:481-510.

Hayter, R. 1997. The dynamics of industrial location: The factory, the firm and the production system. Chicester, New York: Wiley.

Hellmer, F.; Friese, C.; Kollros, H.; and Krumbein, W. 1999. Mythos Netzwerke: Regionale Innovationsprozesse zwischen Kontinuität und Wandel (The networking myth: Continuity and change in regional innovation processes). Berlin: Edition Sigma - Bohn.

Hirsch, J. 1990. Kapitalismus ohne Alternative? (Capitalism without alternative?) Hamburg: VSA.

Hodgson, G. M. 1988. Economics and institutions: A manifesto for a modern institutional economics. Cambridge: Polity Press.

Jessop, B. 1992. Fordism and post-Fordism: A critical reformulation. In Pathways to industrialization and regional development, ed. M. Storper and A. J. Scott, 46-69. London, New York: Routledge.

Kahlefendt, N. 2000. Zurück in die Zukunft (Back to the future). Börsenblatt 12 May, 36-39.

Karrasch, I. 1989. Verlagswesen und Buchhandel in der DDR (Book trade and publishing in the G.D.R.). Unpublished Diplomarbeit. Stuttgart: Studiengang Verlagswirtschaft und Verlagsherstellung, Fachhochschule für Druck.

Kenney, M., and Florida, R. 1989. Japan's role in a post-Fordist age. Futures 2:136-151.

Krätke, S., and Scheuplein, C. 2001. Produktionscluster in Ostdeutschland (Production clusters in East Germany). Hamburg: VSA. 
Krugman, P. 1991. Geography and trade. Leuven: Leuven University Press; Cambridge, MA, London: MIT Press.

Krugman, P. 2000. Where in the world is the 'new economic geography'? In The Oxford handbook of economic geography, ed. G. L. Clark, M. P. Feldman and M. S. Gertler, 49-60. Oxford: Oxford University Press.

Lash, S., and Urry, J. 1994. Economies of signs and spaces. Thousand Oaks, CA: Sage.

Lawson, C. 1999. Towards a competence theory of the region. Cambridge Journal of Economics 23:151-166.

Lemke, R. 1992. Verlagswesen und Buchhandel im Osten Deutschlands - Versuch einer Bilanz im Frühjahr 1992 (Book trade and publishing in Eastern Germany - An evaluation). Internal document. Leipzig: Verband der Verlage und Buchhandlungen in Sachsen, Sachsen-Anhalt und Thüringen.

Leyshon, A.; Matless, D.; and Revill, G. 1998. The place of music. New York: Guilford.

Lipietz, A. 1987. Mirages and miracles: The crises of global Fordism. London: Verso.

Lundvall, B.-Å. 1988. Innovation as an interactive process: From user-producer interaction to the national system of innovation. In Technical change and economic theory, ed. G. Dosi, C. Freeman, R. R. Nelson, G. Silverberg and L. L. G., 349-369. London: Pinter.

Maillat, D. 1998. Vom 'Industrial District' zum innovativen Milieu: Ein Beitrag zur Analyse der lokalen Produktionssysteme (From industrial districts to innovative milieus: Towards an analysis of territorial production systems). Geographische Zeitschrift 86:115.

Malecki, E. J. 1991. Technology and economic development: The dynamics of local, regional, and national change. Burnt Mill: Longman; New York: Wiley.

Malmberg, A., and Maskell, P. 2002. The elusive concept of localization economies. Towards a knowledge-based theory of spatial clustering. Environment and Planning A $34: 429-449$. 
Marshall, A. 1920. Principles of economics. 8th ed. Philadelphia: Porcupine Press.

Maskell, P. 2001. Towards a knowledge-based theory of the geographical cluster. Industrial and Corporate Change 10:921-943.

Maskell, P., and Malmberg, A. 1999. Localised learning and industrial competitiveness. Cambridge Journal of Economics 23:167-185.

Massey, D., and Meegan, R. 1982. The anatomy of job loss. London, New York: Methuen.

Menz, G. 1942. Der Deutsche Buchhandel (The German book trade). 2nd ed. Gotha: Perthes.

Nelson, R. R. 1995. Evolutionary theorizing about economic change. Journal of Economic Literature 23:48-90.

Nelson, R. R., and Winter, S. G. 1982. An evolutionary theory of economic change. Cambridge, MA: Harvard University Press.

North, D. C. 1990. Institutions, institutional change and economic performance. Cambridge: Cambridge University Press.

Oinas, P. 1997. On the socio-spatial embeddedness of business firms. Erdkunde 51:23-32.

Peet, R. 1991. Global capitalism. London: Routledge.

Porter, M. E. 1990. The competitive advantage of nations. New York: Free Press.

Porter, M. E. 1998. Clusters and the new economics of competition. Harvard Business Review 76 (November-December):77-90.

Porter, M. E. 2000. Locations, clusters, and company strategy. In The Oxford handbook of economic geography, ed. G. L. Clark, M. P. Feldman and M. S. Gertler, 253-274. Oxford: Oxford University Press.

Power, D. 2002. 'Cultural industries' in Sweden: An assessment of their place in the Swedish economy. Economic Geography 78:103-128.

Power, D., and Hallencreutz, D. 2002. Profiting from creativity? The music industry in Stockholm, Sweden and Kingston, Jamaica. Environment and Planning A 34: forthcoming. 
Prahalad, C., and Hamel, G. 1990. The core competence of the corporation. Harvard Business Review 68 (May-June):79-91.

Pratt, A. 1997. Cultural industries: Guest editorial. Environment and Planning A 29:19111917.

Pyke, F.; Becattini, G.; and Sengenberger, W., eds. 1990. Industrial districts and inter-firm co-operation in Italy. Geneva: International Institute for Labour Studies.

Rigby, D. L., and Essletzbichler, J. 1997. Evolution, process variety, and regional trajectories of technological change in U.S. manufacturing. Economic Geography 73:269-284.

Robles, D. F. 1994. French theories of regulation and conceptions of the international division of labor. New York: St. Martin's.

Rosenberg, N. 1982. Inside the black box: Technology and economics. Cambridge, New York: Cambridge University Press.

Sagurna, M. 2000. Der Medienstandort Leipzig im Freistaat Sachsen (Leipzig's role as a media location in Saxony). In Medienstadt Leipzig: Vom Anspruch zur Wirklichkeit, ed. H. Grunau, W. Kleinwächter und H.-J. Stiehler, 22-30. Leipzig: Monade.

Schönstedt, E. 1991. Der Buchverlag (The book publishing firm). Stuttgart: Metzler-Poeschel. Schubert, D. 2000. Die Stadt Leipzig und die Medien als Wirtschaftsfaktor (The city of Leipzig and the economic importance of media). In Medienstadt Leipzig: Vom Anspruch zur Wirklichkeit, ed. H. Grunau, W. Kleinwächter und H.-J. Stiehler, 33-36. Leipzig: Monade.

Schulz, G. 1989. Buchhandels-Ploetz (Ploetz book trade directory). 4th ed. Freiburg: Ploetz.

Scott A. J. 1988a. New industrial spaces. Flexible production organization and regional development in North America and Western Europe. London: Pion.

Scott A. J. 1988b. Metropolis: From the division of labor to urban form. Berkeley, CA: University of California Press. 
Scott, A. J. 1996. The craft, fashion, and cultural-products industries of Los Angeles: Competitive dynamics and policy dilemmas in a multisectoral image-producing complex. Annals of the Association of American Geographers 86:306-323.

Scott, A. J. 1998. Regions and the world economy: The coming shape of global production, competition, and political order. Oxford, New York: Oxford University Press.

Scott, A. J., and Angel, D. P. 1987. The US semiconductor industry: A locational analysis. Environment and Planning A 19:875-912.

Stadt Leipzig, ed. 2000. Branchenhandbuch Medien: Region Leipzig 2000 (Firm directory of the media industry in Leipzig 2000). Leipzig.

Storper, M. 1992. The limits to globalization: Technology districts and international trade. Economic Geography 68:60-93.

Storper, M. 1995. The resurgence of regional economics, ten years later. European Urban and Regional Studies 2:191-221.

Storper, M. 1997. The regional world. Territorial development in a global economy. New York, London: Guilford.

Storper, M., and Walker, R. 1989. The capitalist imperative. Territory, technology, and industrial growth. New York, Oxford: Basil Blackwell.

Storper, M., and Christopherson, S. 1987. The city as studio, the world as back lot: The impact of vertical disintegration on the location of the motion picture industry. Environment and Planning D: Society and Space 4:305-320.

Taylor, M. 2000. Enterprise, power and embeddedness: An empirical exploration. In The networked firm in a global world: Small firms in new environments, ed. E. Vatne and M. Taylor, 199-233. Aldershot, Burlington: Ashgate.

Tickell, A., and Peck, J. A. 1992. Accumulation, regulation and the geography of postFordism: Missing links in regulationist research. Progress in Human Geography $16: 190-218$. 
Uzzi, B. 1997. Social structure and competition in interfirm networks: The paradox of embeddedness. Administrative Science Quarterly 42:35-67.

v. d. Berg, L.; Braun, L.; and v. Winden, W. 2001. Growth clusters in European metropolitan cities. A comparative analysis of cluster dynamics in the cities of Amsterdam, Eindhoven, Helsinki, Leipzig, Lyon, Manchester, Munich, Rotterdam and Vienna. Aldershot, Burlington, USA: Ashgate.

v. Schroeder, F. 1904/1970. Die Verlegung der Büchermesse von Frankfurt am Main nach Leipzig (The relocation of the book fair from Frankfurt/ Main to Leipzig). Leipzig: v. Jäh \& Schunke (Reprinted by Zentralantiquarit der DDR).

Volpers, H. 1991. Der gesamtdeutsche Buchmarkt 1990/91: Eine Bestandsaufnahme - ein Jahr nach der Vereinigung (The German book market in 1990/91: An evaluation one year after Reunification). Media Perspektiven 11:735-743.

Wittmann, R. 1999. Geschichte des deutschen Buchhandels (History of the German book trade). 2nd ed. Munich: Beck. 
Table 1. Regional Bundles of Family and Community Inheritances (Source: Adapted from Clark, Tracey, and Lawton Smith 2001).

\begin{tabular}{|c|c|c|c|}
\hline & & \multicolumn{2}{|c|}{$\begin{array}{l}\text { Overall family inheritance/ } \\
\text { firm characteristics }\end{array}$} \\
\hline & & Positive & Negative \\
\hline \multirow{2}{*}{$\begin{array}{l}\text { Community inheritance/ } \\
\text { networked regional actors }\end{array}$} & Positive & 1 & 2 \\
\hline & Negative & 3 & 4 \\
\hline
\end{tabular}


Table 2. Regional Bundles of the Leipzig Media Industry in the Pre-War and PostReunification Periods.

\begin{tabular}{|c|c|c|}
\hline \multirow[t]{2}{*}{ Bundle characteristics } & \multicolumn{2}{|c|}{ Leipzig's media industry bundles } \\
\hline & Pre-War period & Post-Reunification period \\
\hline $\begin{array}{l}\text { Dominant media industry } \\
\text { cluster }\end{array}$ & book trade and publishing & $\begin{array}{l}\mathrm{TV} / \text { film production and new } \\
\text { digital media }\end{array}$ \\
\hline $\begin{array}{l}\text { Importance in the regional } \\
\text { economy }\end{array}$ & significant & minor \\
\hline Firm characteristics & $\begin{array}{l}\text { positive (some of the most } \\
\text { important, competitive na- } \\
\text { tional actors) }\end{array}$ & $\begin{array}{l}\text { average (no major national/ } \\
\text { international players) }\end{array}$ \\
\hline Community characteristics & $\begin{array}{l}\text { positive (dense networks of } \\
\text { suppliers/ services; institu- } \\
\text { tional thickness) }\end{array}$ & $\begin{array}{l}\text { average but improving (sup- } \\
\text { plier networks and institu- } \\
\text { tional support are not yet fully } \\
\text { developed) }\end{array}$ \\
\hline $\begin{array}{l}\text { Type of regional bundle } \\
\text { (Clark, Tracey, and Lawton } \\
\text { Smith 2001) }\end{array}$ & $\begin{array}{l}\text { CASE } 1 \text { bundle (positive firm } \\
\text { and community characteris- } \\
\text { tics) }\end{array}$ & $\begin{array}{l}\text { CASE } 4 \text { bundle, possibly on } \\
\text { the way to CASE } 2 \text { or CASE } \\
3 \text { (average firm and commu- } \\
\text { nity characteristics) }\end{array}$ \\
\hline
\end{tabular}


Figure 1. Leipzig and the Administrative Basis of the MDR in Germany, 2000.

Leipzig and the Administrative Basis of the MDR in Germany

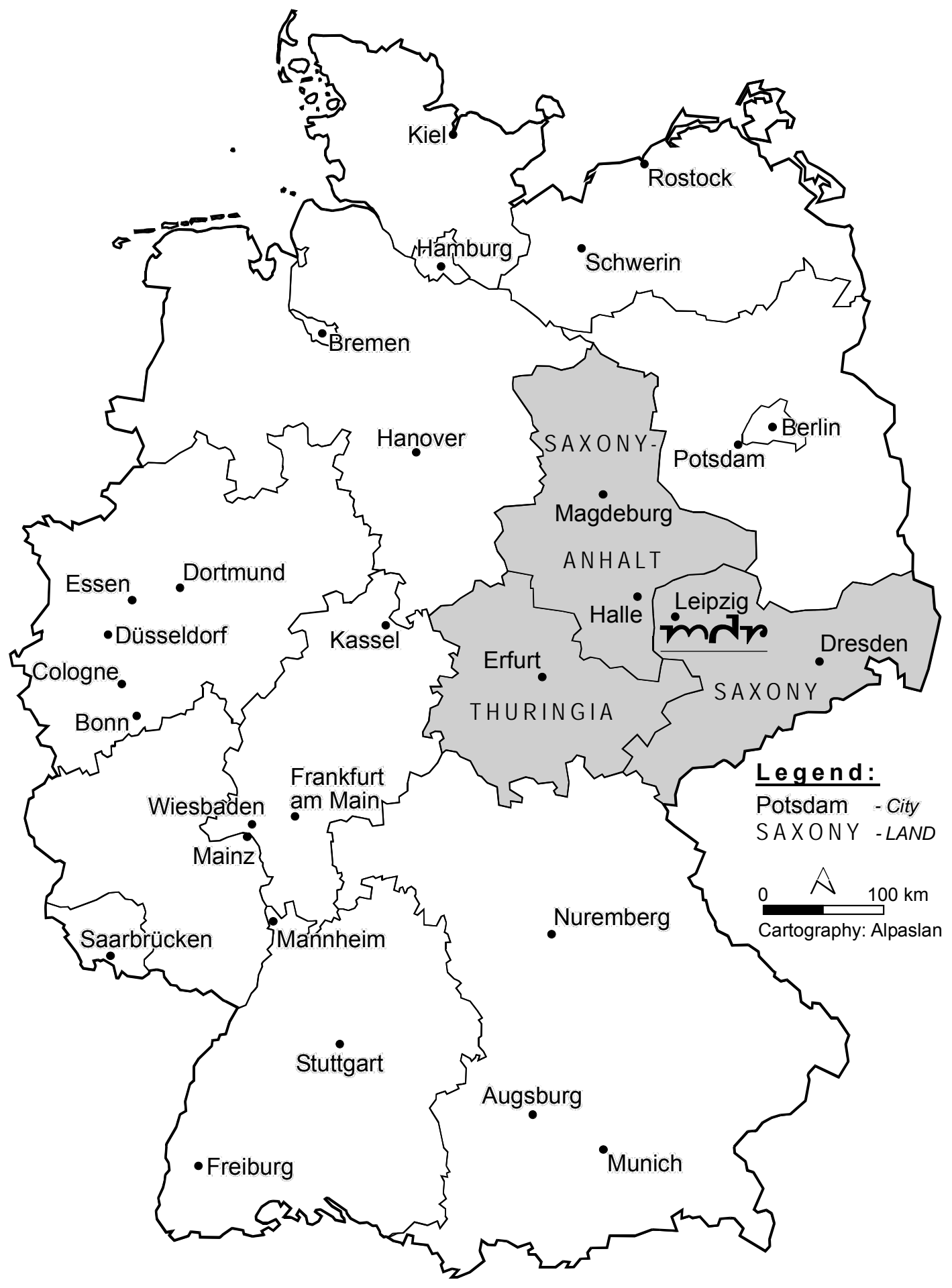


Figure 2. Firms of Leipzig's Book Publishing Industry, 1939 (Source: Adressbücher

Redaktion des Börsenvereins des Deutschen Buchhandels zu Leipzig 1938).

Firms of Leipzig`s Book Publishing Industry, 1938

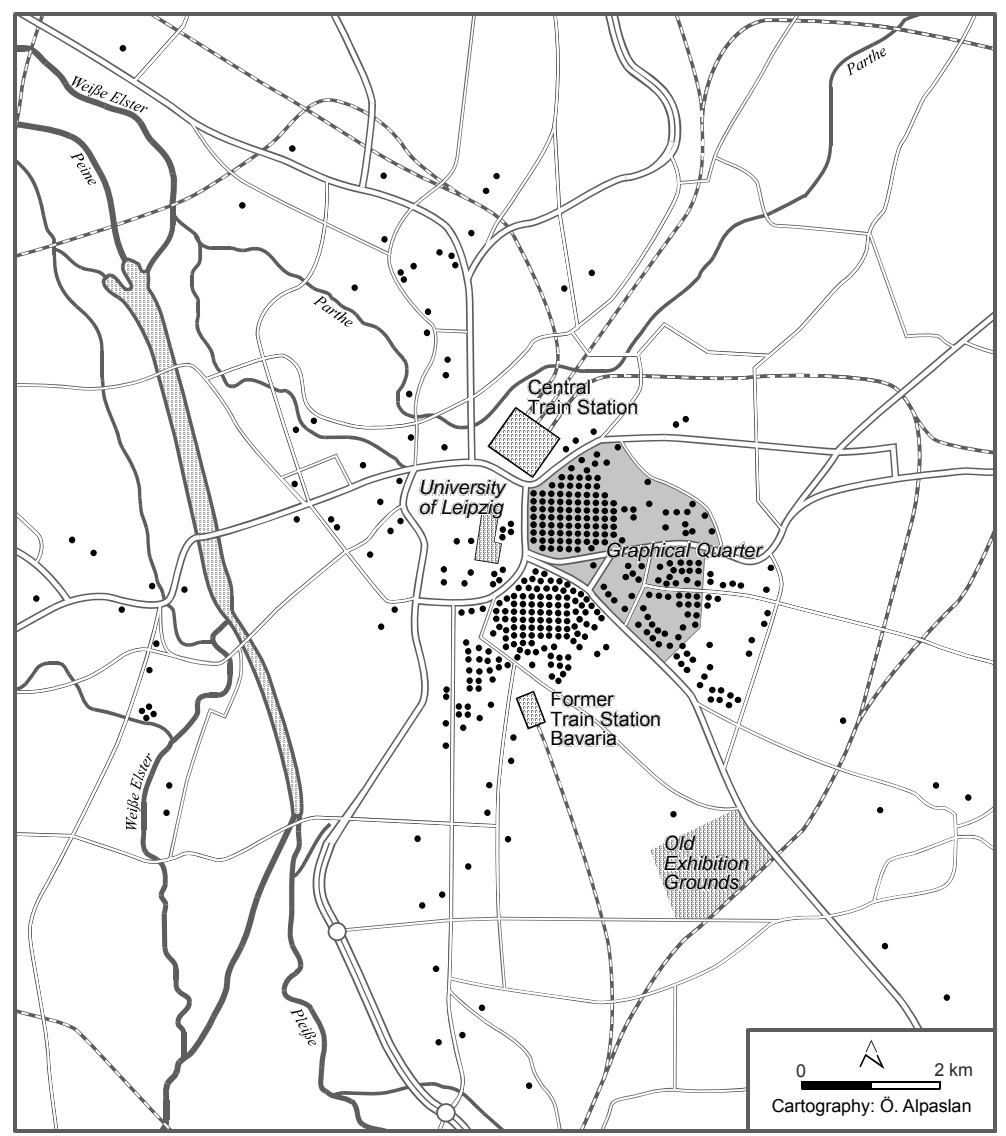


Figure 3. Firms and Institutions of Leipzig's Book Publishing Industry, 2000 (Source:

Stadt Leipzig 2000).

Firms and Institutions of Leipzig’s Book Publishing Industry, 2000

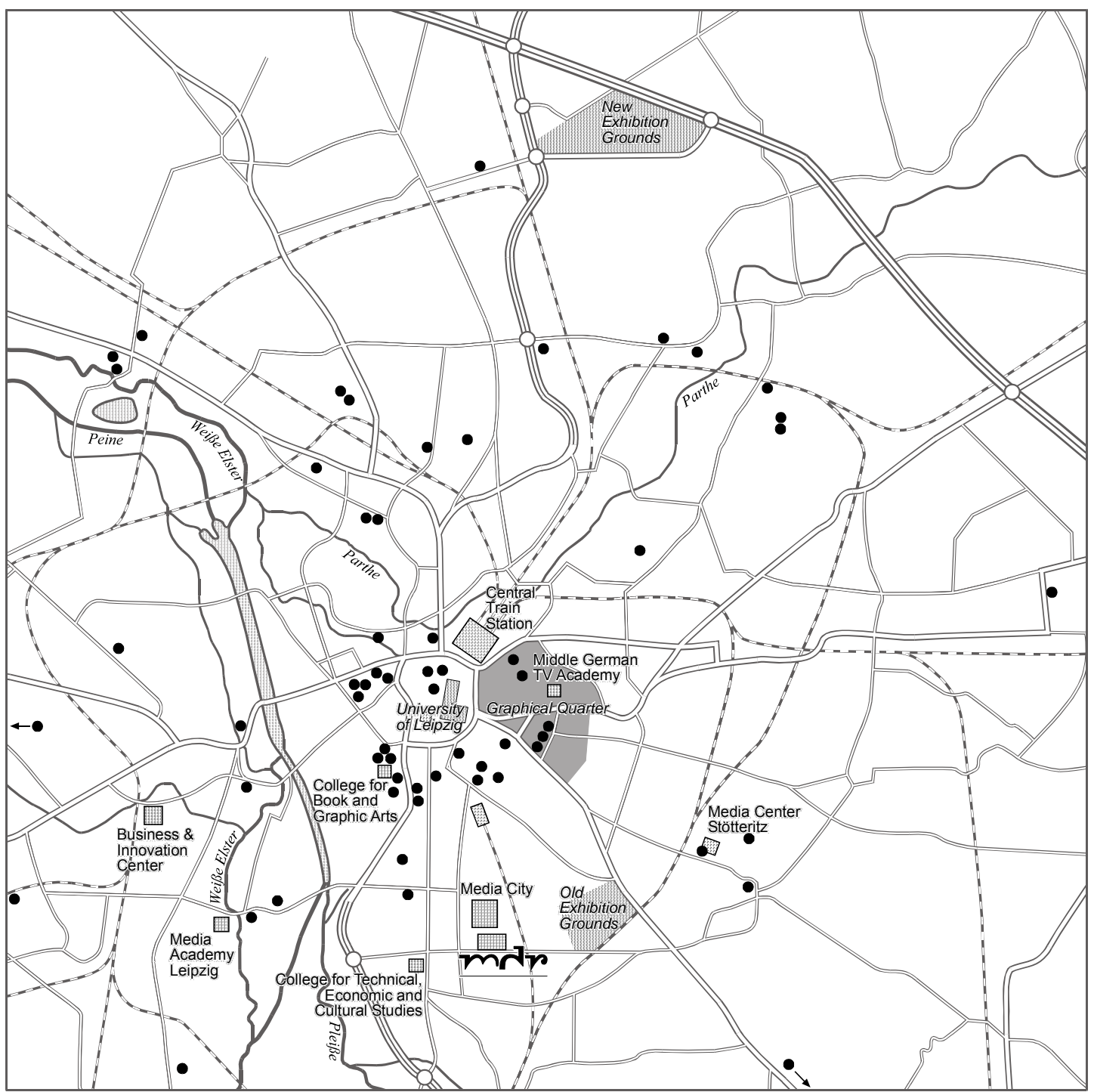

Media Firms by Branch, 2000

- Publishing

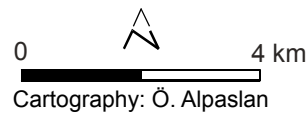


Figure 4. Firms and Institutions of Leipzig's Broadcasting, Film and New Media Industry, 2000 (Source: Stadt Leipzig 2000).

Firms and Institutions of Leipzig`s Broadcasting, Film and New Media Industry, 2000

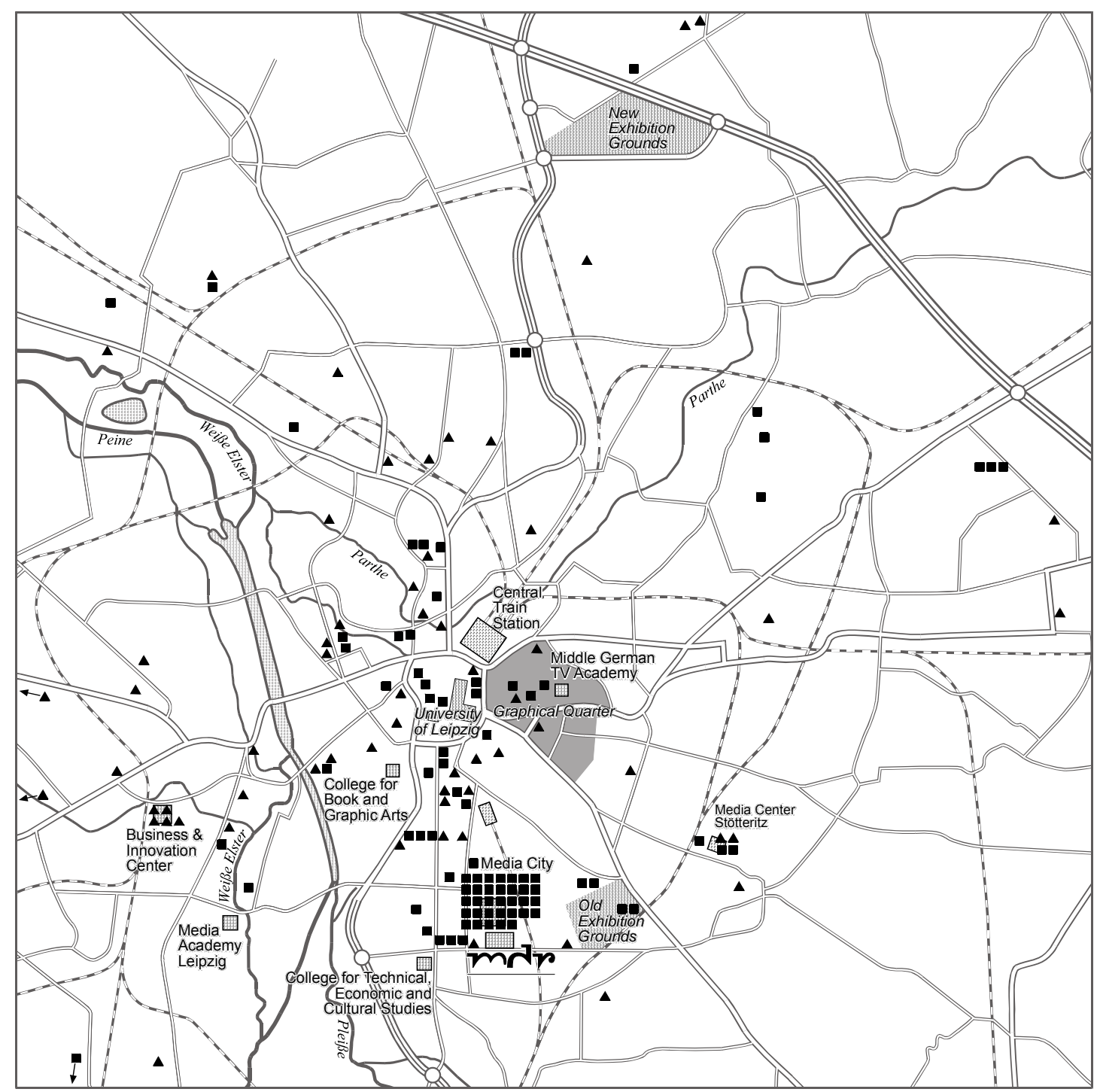

Media Firms by Branch, 2000

- TV/Radio/Film Production

$\hat{N}$

$\Delta$ New Digital Media

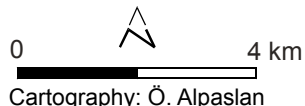


